\title{
Reflections on School Engagement: An Eco-Systemic Review of the Cree School Board's Experience
}

\author{
John Visser \\ University of Northampton \\ Frédéric Fovet \\ McGill University
}

\section{Author Note}

John Visser, Research in the School of Education, University of Northampton, Northampton, UK; Frédéric Fovet, Office for Students with Disabilities, McGill University, Montreal, Quebec, Canada.

Correspondence concerning this article should be addressed to Frédéric Fovet, Office for Students with Disabilities, McGill University. Email: Frederic.fovet@mcgill.ca and Tel: 5143986009.

\begin{abstract}
The parameters are readily interesting: The Cree School Board experience over the past 25 years represents one of the first occurrences worldwide of a society having globally acknowledged that a curriculum, as a whole, did not necessarily fit a specific group, rather than the individuals not performing within a curriculum. As such, this represents a characteristically eco-systemic experiment where a move has been made from the simple-and not-so-unusual observation of poor school performance from a community as a whole-to the conclusion that a curriculum was poorly matched to the group it was set to serve. This assessment has led most notably to the adoption of Cree as the language of instruction in order to increase performance. Statistics for the Cree School Board (CSB), however, are not showing convincing signs of improvement and Cree parents appear increasingly divided in their assessment of how the curriculum now serves their children. The purpose of this article is to throw some light on factors that may explain the difficulties Cree students are facing within school in its present format. The highly topical aspect of this assessment and review is that the characteristics that supposedly make some Cree children difficult to teach in a Western style classroom are attributes often assimilated to children with Social, Emotional, and Behavioural Difficulties (SEBD) in mainstream schools: restlessness, inability to stay indoors, short attention span, rejection of classroom etiquette, and rules. The study suggest that, far from being distinct and dependent on variables that are unique, outcomes such as those recorded in Cree schools, highlight challenges in student engagement encountered by many school environments in the $21^{\text {st }}$ century, particularly inner city schools.
\end{abstract}

Keywords: Cree Nations; eco-systemic analysis; Native education; Social, Emotional, and Behavioural Difficulties (SEBD) 


\section{Reflections on School Engagement: An Eco-Systemic Review of the Cree School Board's Experience}

\section{Context}

The Cree context is not an Indigenous setting that is unique by any means. Issues inherent to Native education or the education of young people growing up in reserves are well documented in Canada (Arbess, 1981; Bell, 2004; Cameron, 1987; Darnell, 1984; Manitoba Education, Citizenship and Youth, 2005; Mendelson, 2008), as well as Australia (Gale, McClay, Christie, \& Harris, 1982; Mills, 1972; Russo, 1983) and Central America (Modiano, 1975). The Cree School Board (CSB), however, offers unique parameters for study in the sense that unprecedented political events unfolding since the 1970s have allowed the Cree to gain autonomous pedagogical, financial, and political control over education policies and administration following the creation of the CSB in 1975. The creation of the school board, shortly followed by the adoption of Cree as a language of instruction in primary education, has set the stage for some unique insight into both the benefits of institutional education in a Native language and culture, and the potential hurdles this may create for Native students who, at a later stage, may be asked to adapt to less congenial academic and vocational environments. The researchers were given the extraordinary opportunity of gaining unlimited access to communities, staff, facilities, and data, a situation having rarely arisen in the past two decades (Blacksmith, 2000; Savides, 2000).

\section{Historical context}

The setting of this study is so particular that it seems important to set the context for the reader before describing the details of the research process. The James Bay Crees, or Eeyouch, are pre-eminent in early Canadian history, encountered by the second wave of European trappers as they ventured inland from the James Bay. In 1668, importantly, the Hudson's Bay Company landed on the shores of James Bay, at the mouth of the Rupert River (Frenette, 1988). With the development of the fur trade, Cree culture from here onwards increasingly developed its own very specific dual lifestyle between bush and trading posts (Niezen, 1988). It had always been the goal of the Hudson's Bay Company to encourage the Cree to settle around the trading posts to facilitate fur trade; however, it would be wrong to view the trading posts as a threat to, or the end of, forest lifestyle. During the summer months, families would establish camps in close proximity to the trading posts (Francis \& Morantz, 1983) and find subsistence in fishing. In the fall, goose camps would be set up along the James Bay coast in order to allow hunting during the goose migration (Niezen, 1998). Once the ice was safe, Cree families would settle into winter camps on their traplines, in isolation on their hunting territory (Frenette, 1988). This dual lifestyle has been maintained through the centuries and even during the growth of the Hudson's Bay Company's trading posts, and in spite of the ongoing flux of workers, missionaries, and workers, the Cree became apt at handling the movement from forest to settlement and at deciphering non-Native expectations while their survival remained firmly based on forest activities (Niezen, 1998). This dual lifestyle is still readily present in the daily life of Cree communities (McLeod, 2007; Scott, 1986). 
With fur trading expanding to the West, Cree land escaped European interest until 1911, when the building of the National Transcontinental Railroad revived interest in the land of Northern Québec and settlers who had eventually turned away from farming, and who had started competing with Cree hunters and trappers further north (Gnarowski, 2002). The over-harvesting of prey and the expansion of settlements created tension with Cree populations until the imposition of beaver quotas by the Federal Government in the 1930s eventually led to the exclusion of non-Natives from trapping (Niezen, 1998). This in turn restored fur-trading relations to a situation where Cree hunters once again exercised sole control over their traplines (Scott, 1988). With this though came an increased desire for direct involvement in Cree affairs from the Federal government, particularly in terms of administrative presence within settlements. Beyond the very real threat presented by epidemics brought by non-Native workers (Gagnon \& Rocher, 2002), three institutional interventions, the federal schools, the health initiatives and the appearance of institutionalized churches, at different times and in varying manner, also breached this subtle equilibrium through the $20^{\text {th }}$ century (Niezen, 1998). In the field of education, summer day schools organized by missionaries were progressively replaced by Federal residential schools (Gagnon \& Rocher, 2002). These institutions removed Cree children from their families in order to educate them in either English or French within a residential format, away from their communities and cultures; they functioned on an assimilation agenda, which at times even involved turning a blind eye to harassment and abuse (Bonspiel, 2006, February 17; Indian and Northern Affairs Canada, 2004; Indian Residential School Resolution, 2006; Nichols, 2005;). The memory of the sombre reality of the residential schools is still present in the perceptions that Cree communities have of institutionalized education (Smith, 2013).

Ironically, while stealing away many youngsters from their cultural heritage, the residential schools were also educating a generation of Cree in the languages of the colonisers, giving them the tools necessary to elaborate a new radicalism against the occupants of their land (Gnarowski, 2002). The 70s saw the first generation of young Crees, having received a higher education in the South, returning to claim back recognition of their roots and with it developing some political momentum. As the relationships between Eeyouch and provincial government became more complex, one saw a generation of sons and daughters of trappers and fishermen become executives and take on liberal professions within the new order. On April $30^{\text {th }}, 1971$, the Government of Quebec announced that it unilaterally intended to build three giant hydroelectric complexes on Cree land, which would eventually flood 4054 square miles of Native land. After a long and fierce court battle, the government of Quebec had little choice but to acknowledge for the first time the right of the Cree people through the James Bay and Northern Québec Agreement in 1975. As well as offer large financial compensation, it recognised the right of the Cree people to self-determine their future and aspirations. Article 16 of the James Bay and Northern Québec Agreement (Indian and Northern Affairs Canada, 1993) established a new body, the Cree School Board, and granted it the funding necessary to carry out its mission: to offer a new kind of Cree Education that would move away from the principles of assimilation that had been inherent in the residential school programmes. The school board was formally constituted under the Quebec Education Act in 1978 and 1978-79 was the first official school year under the new board. While the Treaty had given the Cree people the leverage necessary to obtain 
recognition, the principles behind the creation of the CSB were more fundamental than just sporadic political claims. The Cree Way Project, which had began some years back in Waskaganish, had already from 1973 proven the established virtues of re-establishing Cree Language as the language of instruction (Feurer, 1990) and of reclaiming a Native cultural heritage within the education system. The CSB, developed under the terms of the James Bay Agreement in cooperation with the Ministry of Education Quebec, in many ways retains the structure of non-Native school boards in the south of the Province (Smith, 2001).

\section{Geographical Context}

Nine communities in Quebec, at present, form the Cree nations: four inland communities - Mistissini, Oujé-Bougoumou, Waswanapi, and Nemaska—and five Bay area communities-Waskaganish, Eastmain, Weimindji, Chisasibi, and Whapmagoostui (Gnarowski, 2002). There are negotiations for the incorporation of a 10th nation, inland near Val-Dor, to the south of the existing communities (Bonspiel, 2002). There are schools set in each of these nine communities. Each is administered independently by a principal as well as parents committee; the parents committee has a consultative role in the hiring of staff and the administration of the school. At school board level, each Cree community appoints or elects one Cree person to act as a School Board Commissioner. The Board is comprised of these Commissioners. There are variations in size amongst these schools and some specialize in the primary or the secondary sector, as is the case in Waskaganish, while others are all encompassing. Certain schools also offer adult education as a separate service but from the same premises. Each principal remains autonomous in matters of teacher selection and pedagogical supervision. A centralised Pedagogical Services department is based in Chisasibi and its role is that of advice to the schools through a team of consultants, while administrative services for the school board are based in Mistissini (Cree School Board, 2006a).

\section{Ethnological Context}

It is important, in order to understand the concept of community within the Cree culture, to seize its characteristics adequately when it comes to notions of school and education. Apart from summer months spent close to trading posts, which offered a forum for social interaction, Cree populations traditionally did not, and still do not, adopt Western concepts of "structured" social organisation or hierarchies, although they are ruled by their own complex cynegetic cycles and practices. On traplines, meetings of families whose hunting territories are adjacent always focus primarily on a specific activity such as a caribou hunt (Frenette, 1988). These macro-groups are assembled solely for the exploitation of a resource or the practice of a religious activity. This loose and pragmatic connection was the basis of exchange at all levels until the 1970s and made any notion of within classroom education in a year-long format both unfeasible and undesirable. This is still a contemporary challenge and goose hunting for example will take precedence, for families, over classroom attendance (Standing Senate Committee on Aboriginal Peoples, 2011).

Concepts of property are also widely different in Cree culture and this bears

impact on the Cree notion of competence and education. Occupation of land is not based 
on proprietary rights (Niezen, 1998) and Cree culture is more concerned with rights and obligations and conceives land ownership in terms of stewardship and sharing. A tallyman (uиchimaau) is the person responsible for the supervision of the hunting territory, for the coordination of activities on the trapline, and importantly for our purpose, for stewardship, which is inseparable from recognition of competence in Cree men (Scott, 1988), and therefore, also directly relevant to the Cree understanding of education. In terms of teaching, infancy is characterized by parental indulgence and manifestations of affection (Preston, 1979). Quickly though, boys are encouraged to follow their fathers on hunting trips and by age eight most would traditionally have achieved a level of autonomy in the bush. This is symbolized in the important rite of the First Step ceremony, which remains highly relevant in communities to this day and marks the achievement of this first level of autonomy by the child. It involves a walk outside the tepee, with hunting paraphernalia for the boys and gathering equipment for the girls, in front of the assembled community, as well as a symbolic firing of a gun by the boy and the splitting of a bundle of wood by the girl (Tanner, 1979; Visitor, 1999). Subsequent education is done in terms of slow apprenticeship, through the observation of adult activity, until a level of competence within the peer group is achieved (Frenette, 1988; Preston, 1979). This passage to full hunter status is symbolised by the ceremony of the first kill, which takes place in hunting camps and marks the recognition of a young man's social competence.

\section{Current Concerns}

The CSB statistics cumulated for cohorts 1992 to 1998 show a dropout rate situated at approximately $88 \%$ over the nine schools, irrespective of geographical location or school size, which varies widely from approximately 300 to over 1000 for Mistissini and Chisasibi. Eighty-five students graduated from the nine secondary schools in 2006. Absenteeism has varied between $16.4 \%$ and $21.3 \%$ over the last six academic years, the latter figure being that for 2005/06. This represented 30 days of absence on 139 school days for the last academic year (Cree School Board, 2006a). It seems necessary, therefore, to review the curriculum in its present form, and to highlight the factors that might explain why the needs of Cree children are not being met by the school system and why secondary education in particular does not lead to positive learning outcomes. The opening of the Accelerated Christian Education School in Mistissini in the fall of 2006, a fee paying alternative, illustrates the discontentment of certain Cree parents towards the CSB and its performance in its present form (Bonspiel, 2006, October 20). Allegations of within school racism and an enquiry in Mistissini by the Quebec Human Rights Commission in 2004 further stressed Cree concerns about performance and teaching conditions (Bonspiel, 2006, October 20). The CSB has been undergoing a constant reevaluation over the last two decades using a thought process that is eco-systemic in nature, in the sense that it accepts that the factors for poor performance may be much farther reaching than the schools themselves and that solutions will have to involve communities and Cree society as a whole. As Cooper, Smith, and Upton (1994) explain:

Systemic theories have been advanced which seek to understand behaviour problems in schools in terms of the interactions of the persons involved, either within school situation or in related contexts such as the family of the pupil concerned, the staff group etc. (p.25) 
Clearly, this eco-systemic review must go a little further yet.

\section{Review of Existing Literature}

Poor performance and attendance are phenomena that have been reported throughout Native communities in Canada. Most theorists accept the fact that the causes may be varied and complex, and may involve a phenomenally wide spectrum of variables. It is, therefore, essential that this study not limit itself to one single hypothesis, a process that would appear simplistic. The ecosystemic theoretical framework adopted for the study inherently requires the consideration of multiple causal factors at various scales. Of the many hypotheses that can be and have been raised when attempting to evaluate the causes of low performance in Native students within formal style classrooms, the study selects four for further consideration: (a) language of instruction, (b) post-colonialist mechanisms, (c) issues of tradition, and (d) the rejection of sedentary lifestyle.

\section{Language Policy Issues}

One of the working hypotheses of this paper is the notion that poor outcomes in Cree schools might be caused by the failure to integrate Cree effectively as language of instruction. Much of the literature, since the early 70s, points towards the benefit of teaching Native students in their language. First, language is not used in the same ways for communication in Cree society as it is in non-Native exchanges (Darnell, 1984), and teaching should, therefore, attempt to reach children through their own communication patterns. Secondly, research suggests that instruction in the Native language is conducive to a higher degree of self-esteem in Native children (Battiste , 2002; Bell, 2004). The experimental foundation for such theories was established in the Cree Nations themselves when the Cree Way Project was put in place in the community of Waskaganish in the early 70s, allowing Cree students to be taught in Cree (Feurer, 1990). The data from this study has been reviewed by linguists and anthropologists because many argue the virtues of re-introducing Native first language teaching as part of instruction (Bostic, 2005; Burnaby, Mackenzie, \& Salt, 1999; Raham, 2004; Wright \& Taylor, 1995). More recently, a large-scale study into Native schools within non-Native school boards in Western Canada yielded similar results and equated academic performance with selfesteem and a school's commitment to reviving instruction in the Native language of the communities (Bell, 2004). The CSB has long ago adopted the Cree Language of Instruction Programme (CLIP), which has been systematically applied at primarily level, with a progressive introduction of French and/or English in the early years of secondary school. It may seem contradictory, in light of the overwhelming support research seems to be showing this initiative, to be raising the language policy issue as a working hypothesis for low performance. It is, however, an argument that is raised within the community itself (Bonspiel, 2006, October 20) and one that accordingly needs be addressed: The Voyageur School in Mistissini, in fact, abandoned the CLIP programme in 2006.

\section{Total Institution Syndrome and Post-Colonialism}

While racism may be a politically charged word and one not necessarily suited to the educational context observed in the Cree communities, there seems on the other hand to be supporting literature to explain a lack of fitness between Native student and, often, 
non-Native teacher. Niezen (1998) points out how federal residential schools established themselves as total institutions. In this respect, Niezen draws on Goffman's (1959, as cited in Davies, 1989) theory of global institutions:

Total institutions do not really look for cultural victory. They create and sustain a particular kind of tension between the home world and the institutional world and use the persistent tension as strategic leverage in the management of men. (p. 10)

Niezen (1998) draws a parallel between the control, which was exercised by non-Native teachers in residential schools and the feeling of helplessness and submission experienced by patients in mental institutions and boarders in boarding school. This phenomenon may not have been eliminated with the closure of residential schools. Bérubé (1994), indeed, suggests that the mechanisms of total institutions may not have completely disappeared from the modern day classroom in the context of the CSB. Behavioural models, similar to that illustrated by Haney, Banks, and Zimbardo (1973) in their now infamous study, can lead one to conceive that teaching staff in remote and unfamiliar locations might seize what control they retain through overzealous classroom management. Group identity and group preference theories (Tajfel, 1970) also come into play between non-Native teachers and Native students, irrespective of what good pedagogy might dictate, particularly in situation where they are uprooted in a context remote from home (Hall \& Fovet, 2012).

As for post-colonialism, this describes the period following the passing over of power in colonised states to rulers born and bred in these territories themselves (Ahamad, 1995), which aptly defines the current ascension of the class of rulers and negotiators having achieved recognition of Cree interests post-1970 (Gnarowski, 2002; Niezen, 1998). The prefix post in post-colonial also suggests a change in power structure after the end of the regime of colonialism but often also indicates a continuum in practices (Chakrabarty, 1992; Spivak, 1990). The hypothesis that the practices in education established in the old order that have been maintained in the new must be considered (Kumar, 2000). These practices are often discussed in the communities themselves (Bonspiel, 2006, October 20) as well as by theorists (Flanagan, 2002; Morantz, 2002b).

\section{Traditions and Culture}

The importance of hunting and fishing traditions within Cree culture have been well documented (Felt, 1995). The difficulties in retaining these traditions and the pragmatic knowledge of bush life in the face of modernism and globalisation have also been extensively documented (Tsuiji, 1996). It would appear that traditional classroom education reduces the time available for the transmission of essential bush skills because these were based principally on participant observation (Preston, 1979) and apprenticeship in the bush itself; it is suggested by the literature that this slow culture erosion leaves young Crees ill-equipped (Ohmagari \& Berkes, 1997). Observing the transmission of 93 bush skills amongst Native women, the researchers found that over half were no longer being transmitted to young women formally educated. There have been attempts to remedy this phenomenon in Native communities within the schools, with the introduction of Cree cultural programmes (Alberta Education, 1989), and within the communities themselves, with the intervention of elders (Roué, 2006). The mission statement of the CSB (2006b) states: 


\section{Cree language and culture are the root of the Cree education system}

We believe that the Cree child:

Has the right to be taught and practice his or her culture and its value system;

...[and]

is to be provided the opportunity to follow any level of academic, technical, vocational and Cree traditional education.

The hypothesis that the Cree School has not successfully retained the transmission of Cree heritage within the curriculum, and that it remains a vehicle for competencies that do not have a Native flavour or focus, needs to be addressed in addressing poor outcomes.

\section{Nomadic Parameters}

Research suggests that traditional Cree culture was never based on principles of close proximity within an established social structure in Western terms (Frenette, 1988; Niezen, 1998). The population was often dispersed and made up of semi-nomadic hunters, who only regrouped and socialized sporadically based on kinship and convenience to coordinate specific activities. Preston (1979) notes a distinct lack of integral social structures amongst Cree populations. It is argued by Niezen (1998) that, far from being people who submit to the process of cultural assimilation, the Cree are "people who have largely succeeded in defying such a pattern of cultural homogenization, at least for the present and foreseeable future” (p.2).

This applies particularly to western concepts of sedentary living. Even the concept of belonging to a community depends more on Western classification methods and definitions established in the Indian Act than on a true attachment to a geographical location (Frenette, 1988; Gagnon \& Rocher, 2002); trading posts having always been little more than temporary meeting places between Native and non-Natives during the fur trade (Francis \& Morantz, 1983). Most community locations, in fact, have since been moved from their original location as trading posts, following the construction of the hydroelectric projects and flooding of the 1970s (Gagnon \& Rocher, 2002). Niezen (1998) emphasizes the misconception that sedentary living is now readily accepted in Cree communities when he examines in particular the phenomenon of social pathology that followed the forced relocation of the Fort George families to Chisasibi. Niezen also notes the requirement for children to attend school as a key element in forced compliance with relocation. Many Cree families retain hunting and fishing camps in spite of post1970s efforts to establish forced settlements (Felt, 1995). This semi-nomadic lifestyle has clear repercussions on performance and absenteeism of children in schools; the requirement for school attendance is experienced by some parents as a threat to their ability to move freely and a constraint on their chosen lifestyle (Canadian Council on Learning, 2008). A parallel can be seen with issues currently being researched in relation to the education of traveller children in the UK and Europe (European Monitoring Centre on Racism and Xenophobia, 2006; Padfield \& Jordan, 2004; Yorkshire Museums, Libraries \& Archives Council, 2005). The hypothesis that a lack of fit exists between the 
Western notion of schooling and non-sedentary living is, therefore, a lens, which must be considered in this study.

\section{Methodology}

Native education settings are distinct environments and exploring them requires some intensive scrutiny about the methodological processes adopted. Ideally, ethnographic processes would always be preferable when investigating environments where modes of interpersonal exchange may differ widely from the framework of our Western notions of formal interview (Whitehead, 2004). Such methodological processes, however, lay beyond the scope of this study; the researchers had to proceed in a context where many participants might in fact be non-Native and where access to Native teachers and community members might be so restricted by non-Native administrators as to render wide and complex ethnographic processes impossible in practice (Bernard, 2002; Chilisa, 2012). Post-colonialism is a daily reality of modern Native communities and it would be wishful thinking to hypothesize that access to Native teachers and employees can always be gained at will; the control of non-Native consultants over research topics and desired research outcomes is still tangible in many Canadian Native communities and the Cree Nations are no exception to this phenomenon (Williams, Guenther, \& Arnott, 2011). A mixed methodology framework was, therefore, adopted in order to collect with ease all available data from the non-Native participants familiar and at ease with such methods, while leaving space for non-directive ethnographic work with Native participants if circumstances allowed (Elliott, 2004;Tashakkori \& Teddlie, 2003). The impact of methodological choices on research outcomes in Native communities is considerable and can create significant loss of validity (Blagg, 2011); many established qualitative methods such a semi-directive interviews with face to face eye contact, or focus groups have shown to be highly insensitive to community customs (Nicholls, 2009); they may also lead to actual misinterpretation (Laycock, Walker, Harrison, \& Brands, 2011). These concerns and the need for cultural sensitivity were kept at the forefront of the interviews with Native teachers.

\section{Eco-Systemic Evaluation Methods}

The Native context suggests that it is particularly likely that the variables at play in the outcomes observed are numerous (Coates, 2003). An ecosystemic framework for the analysis of data is, therefore, particularly appealing. The fundamental eco-systemic notion is that behaviour and performance are better understood within the context in which they take place (Cooper, Smith, \& Upton, 1994). This theoretical model also implies a willingness to evaluate the full scope of the child's systems in order to determine where a lack of fit between child and environment may be occurring. Ecosystemic methods of evaluation were chosen for this project in the sense that questionnaires, both quantitative and qualitative, led interviewees not merely onto matters of classroom performance and behaviour but also scrutinized perceptions and experiences with regards to school management, administrative procedures, parental involvement, community response, involvement of Elders, traditions, historical context, and socioeconomic reality (Castellano, 2004). In many respects, the hypothesis that numerous and diverse variables are at play in this complex educational context may be true of other non-Native educational contexts. This is one of the appeals of this study: It does not 
purport to establish that the interaction of variables causing the phenomenon of school disengagement is unique to the Cree context. It merely suggests that the variables are so amplified as to be more easily recorded and analysed. It will be suggested in the outcome section that in fact many of the analyses carried in this context bear consideration in other educational contexts, particularly in the field of social and emotional behaviour difficulties (SEBD): inner city schools, special education settings, and so forth.

\section{Visits to the Communities and Observation}

Over nine months in 2008, six of the nine communities were visited for the purpose of this paper. All four inland communities were visited, together with two of the five James Bay communities. The communities of Waskaganish and Eastmain were not visited because no response was obtained from the respective heads of schools. Wapmagoostui was not included in the study because of its extreme geographical remoteness and the impossibility of travelling to the community by road vehicle. In all other cases, the community was visited, a school visit was made to the secondary school, and in certain cases, classes were observed.

\section{Qualitative Interviews}

Qualitative questionnaires were used to survey past and present administrators and heads of the CSB. Eighteen interviews were carried out over the duration of the study; three of which involved a Native interviewee. These ratios are disappointing but reflect perhaps some of the tension that is present within the CSB: Access to participants had to be obtained via non-Native administrators who may wish to ensure that the methodology put into practice provides a favourable reflection on their policies and practices. This is not a unique phenomenon, having been observed in other educational settings such as special education provisions (MacNab, Visser, \& Daniels, 2007). A bias in teacher sampling is an almost inevitable occurrence when school administrators act as gatekeeper and have a vested interest in outcome analysis (Wanat, 2008). A further four interviews were carried out with Native members of the communities who were not involved in the CSB and individuals having spent extensive periods in the communities in various capacities. Informed consent was obtained from all participants. Semi-directive questionnaires, completed during pre-scheduled formal interviews, arranged through email contact, were the basis of this part of the study. Fewer heads than originally contemplated were interviewed because the turnover within the period of study proved to be considerable, a phenomenon that is wide spread in Native schools (White \& Peters, 2009), those not leaving the school board being rapidly promoted to senior administrative positions. The format of the qualitative interview was highly suitable for data collection from non-Native participants; however, it did not prove adequate in the case of Native participants. The limitations in time and the format of the interview were not ethnographic enough to obtain substantial feedback from Native participants and the cultural barriers observed during these meetings were numerous (Smith, 1999). The few Native participants themselves, in particular, mentioned that observation, rather than formal questionnaire, might be more culturally adequate as a research process. It was also mentioned that narratives would be a culturally sensitive process to collect data on the various dynamics at play in the schools but narrative methodology requires the establishment of a relationship between the researcher and the community (Kovach, 
2010). The notion that a person who is not a member of the community or known to its members might expect to get answer to directly formulated questions about community expectations with regards to education seemed optimistic at the very least (Edwards, Lund, Mitchell, \& Anderson, 2008). A tangible degree of suspicion exists within the communities towards any outsider, a phenomenon that is easily understood in light of the socio-historical context detailed above. Furthermore, the Cree communities, as most Native communities around the world, have been over-researched by sometimes less than scrupulous researchers in the past (Royal Commission on Aboriginal Peoples, 1996). The study, therefore, does not purport to present an ethnographic exploration of the perceptions of all actors, but simply a snapshot of the positions of the partners involved (Goulet, 2001; Stewart, 2005). It is also a finding of the study that access to Native employees was actively hindered by non-Native administrators. Here again the hypothesis that, as gatekeepers, most school administrators have a vested interest in the selection of samples relating to the outcomes of own policies must be considered (MacNab et al., 2007). It does represent valid representation of some of the power dynamics present in the communities and the schools (St. Denis \& Hampton, 2002; Wotherspoon, 2008).

\section{Quantitative Interviews}

It was originally hoped that a fully directive quantitative questionnaire would be disseminated amongst teachers during school visits. This proved difficult because access to specific teachers was often limited during visits while classes were in progress. It was decided that the questionnaire would be passed in written form to the teachers through the heads. Again, this process proved to be difficult, in spite of support from the Supervisor of Schools, due to the substantial change amongst heads of school over the duration of the research project. Each head is autonomously responsible for the hiring and supervision of teachers within each school and there could be no substitute to a formal authorization from each head in this process. This was not always forthcoming. The quantitative questionnaire was fairly long (47 questions) and required at least an hour to complete. Retrospectively, it is judged that this was in all likelihood also an obstacle to obtaining a greater number of completed questionnaires. The quantitative questionnaire also carried a warning that completion of the questionnaire amounted to the giving of formal informed consent although it also allowed the teachers to remain anonymous. In total, comments from 10 teachers were collected, two of whom were Native; this represented a rate of return of approximately $11 \%$. During some visits, and some classroom observations, teachers who were met face to face offered comments beyond the parameters of the questionnaire itself and these were then taped and used for a qualitative purpose, consolidating the qualitative data collection carried on separately through the interviews.

\section{Ethical Considerations}

Several ethical issues became apparent during the course of the research project:

1. An ethnocentric issue became apparent in the format of the study. It became quickly clear that response from Native interviewees to the questionnaires was poor and limited in scope. It was felt that ethnologically semi or fully directive 
questionnaires may be ill adapted to interaction in Cree culture. This is highlighted by Darnell (1984) who suggests that use of language in face to face meetings and interviews may be construed very differently in Native culture (Santoro, Reid, Crawford, \& Simpson, 2011). Any research project within Native communities will be confronted by this inherent difficulty. A fairly large body of research and writing on Indigenous methodology is emerging (Smith, 1999) and communities and Indigenous scholars are investing considerable momentum in rethinking qualitative processes within culturally sensitive parameters that are not Eurocentric (Nicholls, 2009). Two Native administrators did not meet for an interview following their initial acceptance. Two Cree Heads of school did not respond to offers to meet for an interview. One Cree administrator expressed anxiety at the prospect of the interview to her supervisor. Several Native participants suggested different processes of data recording might be more sensitive than interviews and questionnaires. With more emphasis within Cree society on silence than speech within social interaction, a wariness of direct eye contact and direct questions (Darnell, 1984), research interviews may have to be led in a dramatically different manner and over much longer periods of time to bear fruit (McNinch, 1994; Simpson \& Driben, 2000). Observation of interactions, quiet presence, and emphasis on listening to unsolicited exchanges were approaches that were suggested by some of the Cree participants in the study. Ethnographic methodology suggests ensuring that the researcher observes a research context before selecting processes, thus ensuring they are culturally adequate and valid (Laycock et al., 2011; Kovach, 2010; Schnarch, 2004). Time was insufficient here to carry out this adaptation once concerns materialized. Observation, centred or comprehensive interviews, and practices inspired by ethnomethodology (Friesen \& Orr, 1996; St. Denis, 2002) may be preferable in future research.

2. Data collected from teachers only has a limited validity within this study. Not only was the process of data collection less than systematic due to difficulties experienced in gaining access to teaching staff, but also it is also felt that the complete control the respective principals of schools exert over hiring, assessment, and supervision might have led to forced outcomes in terms of willingness or refusal to participate in the study. These are dynamics that have been observed previously in the literature (National Center for Education Statistics, 2008; Villegas, Neugebauer, \& Venegas, 2008). It is also ethically unclear whether a bias may have existed in the selection process that the principals used when disseminating the questionnaires to staff. Further, the ratio of Native to non-Native teachers who participated did not reflect the ratio that currently exists within CSB teaching staff (Schnarch, 2004).

3. Furthermore, it is arguable that administration staff, while overall exhibiting willingness to participate, may be seen as having their own understanding of performance issues and as having predetermined explanations for these. Teachers' perceptions of the dynamics that lead to issues in performance, on the other hand, may be tainted by their own motivations, classroom experiences, or ethnicity. We felt that, although this was not possible within the framework of this study, an 
investigation of students' and parents' perceptions and experiences is highly desirable in any future research (Denzin, Lincoln, \& Smith, 2008).

4. Several Native and non-Native interviewees remarked that Cree culture was a "no blame" culture and that it was very rare of members of the community to indulge in "finger pointing." Native participants in particular explained that often community discussions take the form of the circle as mode of exchange, where individual responsibility matters less than global community empowerment. There are echoes of these resolution processes (Nabigon, Hagey, Webster, \& MacKay, 1998) in the recent literature on restorative justice in Canadian Native communities, which coincides with the growing realization amongst non-Native researchers that the notion of individual accountability is often less pressing in Native contexts than the concept of global community response (Sawatsky, 2009). Pushed to its logical consequence, this is seen by many as the reason in the CSB why so little formal assessment or evaluation has been carried out in relation to past initiatives and practices (Weber-Pillwax, 2001; Wright, 1988). This is somewhat counterbalanced by the clear commitment the CSB makes in its mission statement to scrutiny and good practice but may still constitute a partial cultural hurdle to effective research that must have affected this project to some degree (Steinhauer, 2002).

\section{Findings}

It seems befitting to have chosen an eco-systemic evaluation method to review performance within the CSB because this theoretical model seems to be underpinning much of the current work within the board itself. There is a general willingness on the part of Pedagogical Services to look beyond classroom behaviour and academic performance to find the causes of the symptoms observed, and a desire to consider issues arising from the community, the school, or family structure and to find new directions through a process of acceptance and change. If one considers the philosophy statement of the CSB it is also very much student centered and incorporates principles in line with the Accept, Respect, and Changed (ARC) policy developed in certain western school systems (Ali et al., 1997).

\section{The Cree Language of Instruction Program (CLIP)}

It seems generally accepted that the CLIP program is producing satisfactory results at a primary level. Teachers and administrators often note that this leads to added confidence in youngsters. There seems, however, to be both doubt and confusion when it comes to considering the desire-if any-to extend the CLIP program to the end of secondary Level 5 (to age 16 or 17), and secondly, to considering the way students reintegrate French or English classrooms at the end of the CLIP program in secondary Level 1 or 2 (to age 11 or 12). The criticism that comes back regularly is the fact that, depending on school or individual classroom, French or English is introduced in secondary one to five not as a second language as should be the case, but as a first language of instruction. It seems unavoidable that low performance will emanate from the requirement for students to meet standards in a language that had not been (up to that point) their language of instruction. Administrators and heads suggest that the lack of applicants is the reason why so few second language teachers are employed by the CSB. There also seems to be a distinct lack of research or concrete findings when it comes to 
assessing the way students will be transferring skills from the acquisition of Cree into the learning process in English or French (Fillmore, 1991). However, some research into English transition in the context of the Maori setting (Hill, 2007) suggests that the issue here may be one of teacher training rather than a genuine lack of viability for English transition.

Several interviewees pointed to a level of ethnocentrism in the pedagogical material itself and to a dichotomy between the Western style syllabus-adopted from the Ministry of Education of Quebec - and a language of instruction, which often has no words to describe some of the concept to be taught; this was a concern expressed by Cree participants. The Cree Nations have expended considerable effort to update the Cree language and create missing words for concepts imported from Euro-Canadian society and the Quebec curriculum (Morgan, 2002). There is, however, no effort at present from the Ministère de l'éducation, des loisirs et des sports (MELS) to incorporate Cree cultural concepts into the curriculum or to frame the learning material within concrete aspects of community life (Gagné, 2006). This potential pitfall has been identified in other Native contexts such as Nunavut (Denny, 1981; Tulloch, Holt, Pilakapsi, \& Lyall, 2007), and it requires attention and much work from the pedagogical teams in charge of adaptation or conception of material.

Other interviewees suggest that the weakness of the CLIP programme may lay in the format and standards of the Certificate in Cree Literacy Education, the part-time teacher-training programme offered within the communities. Some have suggested that the programme is excessively weakened by being extended over too many years of sporadic study and attendance. Some have also suggested that applicants may be of poor standards at the start. One interviewee felt that some teachers were only one or two years ahead of their students in terms of literacy and mastery of the written syllabic Cree. In review of the Sharing Our Success: More Case Studies in Aboriginal Schools, Raham (2004) wrote:

Until aboriginal languages are accepted by all provincial education authorities for high school graduation credits and by universities in fulfilling second language entrance requirements, a continued shortage of Aboriginal students entering teacher training programs fluent in their own language may be anticipated. (p.33)

The same paradoxical situation seems to hold true for the James Bay Cree communities. Finally, some argue that the content of the course itself may not be satisfactory or providing trainee teachers with sufficient bases for teaching, in light particularly of the relative difficulty that acquiring a written knowledge of Cree grammar represents. One interviewee suggested that the lack of credibility felt by many parents towards the value and standards of the Certificate in Cree Literacy Education might have far greater impact on their attitude to the schools and their sometimes-clear distrust, than the historical impact of the residential schools. The interviewee suggested that in too many cases the Certificate in Cree Literacy Education was seen as a recourse option, one with few selection criteria and that parents had obvious suspicion towards members of the community who may have been their peers, dropped out before the end of secondary education and been seen themselves as "at risk" and who yet might now be teaching their children. 
There is much needed research to be carried out on the way the CLIP programme affects language acquisitions and how best to transfer those skills to other languages or other learning processes. The fact that Cree is not an Indo-European language and does not share the Western alphabet makes transition from one to the other, if indeed there is to be second language acquisition of French and English with the CSB programme, both a fascinating and a rich area for research and improvement, one that might benefit Indigenous teaching and language acquisition programme in other parts of the world. It is surprising that there has been so little research in this area after the large and varied academic coverage that followed the pioneering work of the Cree Way project in the 1970s. As Raham (2004) explains, concerning Western Canada, "more in-depth and quantitative research is needed to obtain a robust understanding of effective practices and approaches in the delivery of literacy and language instruction for Aboriginal students" (p. 4).

\section{Teacher Attitudes in the Classroom}

More than simply a post-colonial attitude or manifestation of the dynamics of total institution, many thought that the sometimes-poor engagement skills of non-Native teachers could be explained in two ways. First, for the older members of staff, it could be explained by a desire to adhere to a more traditional format of teaching now not in line with the Quebec Education Plan. Here training and past experience in other school boards could be seen as the cause of the lack of flexibility, which in turn seemed to alienate students. Second, in other cases, although these younger teachers had received much more recent training, probably more in line with the QEP, it was perhaps that their age led them to manifest insecurities when first faced with challenging behaviours so soon after completing training. Pedagogical services explained that a new teacher-mentoring programme was in early stages of conception; the benefits of such a programme have been documented elsewhere in Canada (Fantilli \& McDougall, 2007). However, it is feared that far from disappearing, these symptoms may increase in the future with an increased availability of teaching jobs in the South and a predicted reduction in the number of applications within the CSB. In addition, it was also felt that the motivation factors of non-Native teachers should perhaps be scrutinised. There is little research available at this stage into the motivation factors that come into play when non-Native teachers apply for positions in the CSB. There is little doubt, however, in the mind of most interviewees that the motivation too often may be either a desire to take on the rather insurmountable goal of helping others or a desire to take a respite from their own emotional history. These remarks echo the findings of literature on teacher attrition in several Native educational settings around the globe and seem to reflect the reality many communities experience (Hall, 2012). Interestingly, these are phenomena also observed in "difficult" schools, in non-Native contexts, such as SEBD schools (Hall \& Fovet, 2012). Pedagogical Services confirmed that there was a desire on their part to perhaps look back and profile the ideal non-Native candidate in an attempt to weed out motivations that were not conducive to the establishment or development of good skills of engagement with the students. While this may prove a delicate exercise, the benefits of such an analysis would be twofold: It might help to achieve some form of profiling, helping to identify the teachers that are ill-equipped for this context from the pool of applicants, and secondly, it might help identify the qualities and skills that allow a non- 
Native teacher to be highly efficient and well adapted in this context. In turn, this could form the basis for a new teacher mentoring and training programme, during which those elements found to be crucial might be taught and enhanced in others. This may also have relevance for others in the field of SEBD.

\section{Tradition and Culture}

It seems to be felt overwhelmingly that there is a need to bring further traditional skills acquisition within the classroom. In addition, it is felt by many that two hours a week of Cree culture teaching is not a sufficient amount of time to be allocated to such a crucial part of the learning process. It is at times also suggested that the Cree teachers currently involved in providing the Cree culture classes are sometimes ill-equipped themselves to provide the knowledge required, as tradition and knowledge are quickly lost or eroded. It is suggested that the idea of a Cree culture certificate, which would be offered in partnership with a university in the South, would be both desirable and possible. It might be perhaps appropriate, as in Western provinces, for even non-Native teachers wishing to work within the CSB to be required to obtain this certificate as a form of training and induction to the classroom culture and the Cree community setting. Efforts have also been made over the past few years to compensate for the lack of heritage training in classroom by placing the emphasis on teaching activities carried out in the bush itself. Considerate efforts and resources have been channelled, for example, into setting up the Anischechistinhimaachewin Alternative Education Program, a pilot project that was set up in 1999 and remained in place until 2004. There is little doubt in most interviewees' mind that, although a closing and exhaustive report was never formally produced, many benefits were brought about by the project which consisted in sending students with behavioural issues into hunting camp situations where they were taught academic subject and bush skills by a teacher and mentor. The programme targeted severe behaviour problems, low self-esteem, poor attendance, social maladjustment, and a slow rate of academic success and over the five years catered for 80 teens. It is acknowledged by all that the reason why the project was halted was that it created a huge financial burden on the CSB: in the region of 15 million dollars over the main three years of operation. There is quite possibly a need to investigate further such alternative projects. One high school principal discussed a plan to take the students of the school into the bush on set days and suggested that this might be an appropriate alternative for all students, not just those with behavioural difficulties. Again, the issue of finding appropriate staff with relevant Cree cultural knowledge was a hurdle, according to many interviewees. The planning and human resources of such projects are also significant hurdles especially within the framework of the union agreement because it is almost impossible to provide such off-site teaching without breaching union conditions and regulations. For these reasons, efforts to allow students access to the acquisition of traditional skills is perhaps best done outside the school itself. This has been developed in Mistissini where the Rangers programme caters to the teaching of non-academic bush and survival skills quite separately from the school. It may be interesting when reviewing the achievements of initiatives such as the Anischechistinhimaachewin project to query whether in fact the benefits of the programme were due to the teaching of Cree cultural traditions and skills or whether the benefits observed arose solely from the fact that youth with behavioural issues were placed within a non-classroom wilderness setting. There 
have been several studies carried out in relation to such outbound projects and many Adventure Based Counselling (ABC) initiatives have been recorded the world over (Sternberg, 1997; Fletcher \& Hinkle, 2002); theories of real world problem solving are also well documented (Nagel, 2001). Whichever the case might be, most interviewees agree that there was both the need for a clear and detailed assessment of the results of the Alternative Education project and a willingness to contemplate further use of $\mathrm{ABC}$ as part of the work of the CSB.

It was suggested, on the other hand, by several interviewees that by placing the word Cree in its denomination, the CSB had taken away much of the radicalism and militant ardour that might still be on display had this not been the case-as can still be observed in Native schools that are part of non-Native school boards elsewhere in the country (Bell, 2004). Its financial and administrative autonomy has been partially reduced; as was noted by some, the determination to emphasize its cultural heritage against non-Natives parameters and practices can be seen as declining. Ironically, by becoming a Native entity, the CSB had lost the need to assert forcefully its uniqueness. The cultural knowledge and identity of youth within the CSB, it is noted by some, is much weaker than that of Native youth who grow up as the minority in a non-Native school board. This observation also seems to be supported by Bell (2004). It was suggested by several administrators and teachers that Aboriginal news, history, and current affairs across bands in Canada and other countries should be incorporated into the syllabus. This is currently taught, in a limited way, in secondary Level 4 (age 14), but a fair percentage of students have dropped out by this stage and do not benefit from this. An Elder when interviewed complained of the lack of Native historical knowledge evidenced in youth within his community even concerning events as recent as the James Bay and Northern Quebec Agreement.

\section{Parental Support and Attitudes}

It is suggested by most interviewees that parental support is weak towards the school and education in general and that parents may have conflicting expectations with respect to the education they desire for their children. This may be due to the impact of the residential schools and to their own upbringing within that context (Indian Residential Schools Resolution, 2006); many feel that the scars of these experiences can still be felt in the distrust displayed by many parents (Bonspiel, 2006, September 2). However, it was also pointed out by some interviewees that the latest wave of parents is parents who were educated within the existing CSB and did not experience the residential school setting. The impact of generational schooling has in fact been shown by the literature to be intergenerational, and one does not need to have experienced it first hand for it to frame one ss perceptions of in-classroom schooling along a Euro-Canadian and Southern format (Chrisjohn \& Young, 1997; Miller, 1996). The conflicted attitude of certain parents however, may also have other deeper and more complex causes and many interviewees echoed the theories of Morantz (2002) and Scott (2002), according to whom forced settlement has led to profound social, economic, and political divisions amongst communities and to a feeling of uncertainty about values and goals. It was suggested here that parental committees, which were originally conceived as consultative bodies, had now become decision-making bodies and as a result have taken up too much place within the CSB administration, notably concerning the hiring of teachers and heads, particularly 
in light of these perceived internal divisions and conflicting expectations. It might be interesting to quantify the attitudes of Cree parents towards the education process and to assess the impact on preconceptions and expectations on parental support, child attendance, child performance, and classroom behaviour. The social and historical impact of colonialism, federal residential school agenda, and missionary policies on the collective Cree conception of education is enormous and needs to be assessed with precision if it is to be addressed and rectified in modern educational formats, particularly in view of the considerable parental involvement in the administration of the school board and political momentum parents committees carry as a decision making body. It will be difficult indeed to work with and integrate the conflicting expectations that are manifest at present until the causes for these conflicts have been recorded and analysed.

\section{Implicating Students}

It was felt by several interviewees that poor performance figures could be explained by the failure on the parts of teachers and schools to motivate students to remain in education until the end of secondary level. There seems, indeed, to be little incentive for students to finish secondary education unless it is to move on to higher education, which is only offered in the South and amounts to an unavoidable departure from communities and families. Although an interviewee pointed out that a first year of CEGEP (2- or 3-year post-secondary college studies) had been started at the Voyageur High School in 2006 (Grand Council of Crees, 2006), there seemed little evidence of either the feasibility of running this programme or the desire to extend it further to create a real collegiate programme offered within the communities. The resilience of students in higher education in the South has been a cause for concern for some time and interviewees generally felt that Cree students are neither academically equipped nor emotionally prepared for some of the challenges that await them in these institutions. It is felt by most that undertones of racism and xenophobia combined with cultural shock make the hurdle of the transition to higher education almost insurmountable. There have been considerable efforts to assist Cree students in this transition and the Cree Pathway pilot programme, run in collaboration with the Aboriginal Student Resource Centre, aims to smooth out this adaptation process (Bonspiel, 2006, September 22). Many interviewees point out that in spite of these initiatives, the percentage of college students who return home without completing their program of studies is extremely high. There have also been efforts made to develop an access to vocational training within the communities: The brand new and well equipped Waswanipi Sabtuaan Regional Vocational Training Centre is being encouraged to open its doors to secondary students and extend its programmes beyond adult education; a consultant explained in interview that his brief was specifically to develop this pathway in the various schools of the CSB. He observed that there seemed to be a general lack of information at classroom level as to the opportunities that were available to Cree students within the sphere of vocational training. He also stated that there was reticence at present and that this option was still seen with a degree of suspicion by many parents as a dropout route; he was also wary that teachers themselves might come to consider this alternative as a "dumping ground" for academically or behaviourally challenged students.

The Director General himself during an interview acknowledged that the CSB had perhaps failed to integrate effectively in its young history other skills acquisition such as 
arts-based abilities, dance, drama, or music. He recognised the need to rapidly develop a chapter of the curriculum that would address and sanction the acquisition of skills that reflected a more artistic or kinesthetic intelligence. It is also difficult when speaking to non-Native administrators and teachers within the CSB not to feel that a level of ethnocentrism persists in our notions and concepts of failure. The phenomenon of teenage resilience beyond the turmoil of adolescence and beyond eventual exclusion increasingly attracts attention from researchers (Ungar, 2002) and it may need to be investigated further within the Cree context. There has not been any concrete research to establish whether school failure and the failure to find grounding and stability in the community in the long term can systematically be equated. Parallel studies in Inuit communities have shown that there is no formality associated with the transition from child to adult in such societies (Barnhardt \& Kawagley, 2005; Córdoba, 2006; Matthiasson, 1979), that schools are not equipped to acknowledge and ease this individual process and that this leads to school failure though not maladjustment within the community.

\section{Absenteeism}

It is estimated amongst interviewees as an accepted figure that the average Cree student misses two years of education out of the prescribed 11, through absenteeism. This seems in line with official figures (Cree School Board, 2006a). Absenteeism in the early years of the CSB was seen by many as caused by a lack of harmony between the traditional Western school calendar and the important seasonal events of Cree life. There is little doubt that, in general, absenteeism is often sanctioned by parents (Visser, 2000) and Cree culture in this respect is no different from Euro-Canadian schools. It is quite frequent, to see families taking children out of school to take part in Goose hunting in the fall. Even though the Ministry of Education school calendar has already been altered, with an early August start and a 2-week holiday for Goose Break in the spring, it is not unusual for parents to leave with their children for the hunting camps far earlier than the official date of the Goose break and for others to return much later, creating an obvious disruption in classroom activities and the learning process. This has led one head of school interviewed to suggest that the problem is so great that it might perhaps be time to look towards initiatives started in Native communities in the West of Canada whereby the year is cut into three terms and students only have a requirement to attend two terms of their choice, enabling them to pursue both traditional lifestyles and academic development. This is not an idea too dissimilar to the original concept of summer missionary schools offering concentrated periods of schooling seasonally (Gnarowski, 2002).

It was argued by many non-Native interviewees though that the traditional bush events could no longer be seen as the cause for absenteeism as many children now choose not to follow families to the hunting camps. It is noted by many that more and more adolescents for example can be seen in the communities over the Goose break, left to their own devices and that many are unwilling to leave for the bush for extended periods. However, a consultant stated that now it is not rare for children to follow their families into the cities on school days or during school time, regardless of the effect this may have on their performance. Some will argue that even if the pursuits are no longer bush related, this tendency illustrates the Cree rejection of sedentary lifestyles discussed in existing literature. Whatever the cause, it is quite clear that with respect to absenteeism, 
prevention is far better than cure (Visser, 2000), though it was observed that many of the interventions at school level within the CSB were still punitive. Research on the children of travellers in Europe yields few tools that may be of use in this particular context, though it offers an interesting parallel on the impact of absenteeism on performance. Many of the recommendations now, indeed, focus on the introduction of IT distance learning tools, which would not be easily adaptable to the huge wilderness that the Cree nations still represent. Western models against truancy such as that devised by Cole, Visser, and Daniels (2001) stress that any effective intervention in this area will presuppose (rather than rigidly impose rules and practices) a dialogue and discussion on practices within the systemic institutions that are schools. This proactive dialogue is perhaps still missing from many of the schools within the CSB and it may represent a rich field for further eco-systemic research.

\section{Discussion}

The work of the CSB, particularly the reflection occurring within the Pedagogical Services department, shows a determination, in the face of poor performance and exacerbated behavioural difficulties, to look beyond the dynamics of the classroom, the requirements of formal learning and simple curriculum content, to various and wide ranging causes that may be at play in the symptoms observed. This deeply seated ecosystemic process proves quickly indispensable when confronted with dropout rates and low performance statistics of such proportion. Yet, when one considers the very classroom symptoms reported by teachers within the CSB as problematic, it is clear that these are not specific to the Cree classroom environment: Excessive movement in class, disregard for classroom etiquette, absenteeism, antagonism, and oppositional defiance with teachers are currently reported in many inner-city schools where student engagement is a challenge and the chasm between the learner and the classroom is vast (Goodman \& Burton, 2010). This reflection, carried out within the exceptionally clear parameters of a geographically and culturally distinct environment and over such a short history, on the failures of a system and the need to adapt it further to cater for students at risk, may be of great significance and direct relevance to any educator seeking to understand the causes that lead to an increase in social, emotional, and behavioural difficulties (SEBDs) within the mainstream classrooms of Western schools. The reviews and hypotheses put forward by the CSB, over its short history, have the great virtue of never falling back on the medical model hypotheses, which are so frequently relied on these days (Conrad, 2007; Wyatt, 2009). This willingness to look beyond within child issues to analyse and comprehend behaviour and performance factors should trigger wider reflection in practitioners further afield.

At a time when the Cree Nations are to benefit from the second part of the Paix des Braves settlement following the Rupert River financial settlement (Cadieux, 2005; Gouvernement du Québec, 2006), it seems essential for the CSB to initiate an assessment of its achievements and failures through its 25-year history. An eco-systemic understanding of the impact of family and community structure as well as social and historical factors has been evident already through its history (Staniforth, 2013). What is perhaps missing is a desire to take those observations to their logical conclusions and to dare question certain features that have to date been retained as given parameters: retention of the predominance of English and French as first languages in the later years 
of secondary education; expectations that progress beyond secondary can only be achieved in non-Native institutions; acceptance of traditional Western teaching programmes as adequate and adapted sources of not just teachers but also teaching formats; and finally, definition of educational failure or success that are mere carbon copies of those notions in other educational systems (Burnaby, Faries, Fietz, \& McAlpine, 1994). As Niezen (1998) observes, the effort of Cree to "incorporate formal administrations into a culture that identifies closely with a quintessentially informal forest economy" (p.5) may not be as contradictory as it appears at first. The Cree, remarks Thistle (1986), have for centuries assimilated Western technology and certain institutional features without this necessarily amounting to cultural decline as they are accepted "devoid of their European ideological content and assigned Indian meanings" (p.35). Niezen (1998) remarks further that "the development of Cree administrations based on southern models does not in itself mean that their values, goals and strategies will be the same as those of parent organisations in non-Native societies” (p.5). Perhaps here lies much of the current difficulties and uncertainty: The Cree may be deep in the complex process of developing a new model of school administration and curriculum, while non-Natives have assumed for too long that the CSB would simply reflect and implement notions and values of school boards elsewhere. The Québec Education Programme, with its wide-ranging reassessment of the goals of education and its focus on skills acquisition rather than content, certainly comes at an apt conjuncture to offer the CSB the context within which to rethink those parameters in the curriculum review it has just initiated. It will offer a framework within which to rethink its needs. In spite of the geographical and cultural idiosyncrasies of its context, the CSB may find that this process is actually very similar to the one which is beginning to be undertaken the world over in order to adapt the aging and ill adapted curriculum contents to a world that has left far behind the Victorian social and economic imperatives that were once the basis for its conception. As Niezen (1998) concludes, "the Cree have developed a form of administrative culture in which relatively efficient bureaucracies can be used to define and defend an Aboriginal way of life" (p. 98). 


\section{References}

Ahamad, A. (1995). The politics of literary post-coloniality. In P. Mongia (Ed.)

Contemporary post-colonial theory (pp. 276-293). London, England: Arnold.

Ali, D., Best, C., Bonathan, M., Bower, D., Cardwell, A., Craik, N., Daniels, A., Dooner, J., Holland, M., Holmes, W., Kingsley, A., Lake, D., McLaughin, A., Martin, N., Peatfield, C., Snowden,W., Vickery, L., \& Williams, H. (1997). Behaviours in schools: A framework for intervention. Birmingham, England: Birmingham Education Department.

Alberta Education. (1989). Cree language and culture program (ECS - Grade 9). Alberta: Government of Alberta. Retrieved from http://education.alberta.ca/media/718636/cree6y_789.pdf

Arbess, S. (1981). Optimizing the environment of the intercultural classroom for the Native Indian student. In S. Arbess, M. Murdock, \& P. Joy. (Eds.), New strategies in Indian Education : Utilizing the Indian child's advantages in the elementary classroom. Victoria, BC: Ministry of Education

Barnhardt, R., \& Kawagley, A. O. (2005). Indigenous knowledge systems and Alaska Native ways of knowing. Anthropology and Education Quarterly, 36(1), 8-23

Battiste, M. (2002) Indigenous knowledge and pedagogy in First Nations education - A literature review with recommendations. Kelowna, BC: Society for the advancement of Excellence in Education. Retrieved from http://www.aincinac.gc.ca/pr/pub/krw/ikp_e.pdf

Bell, D. (with Anderson, K., Fortin, T., Ottoman, J., Rose, S., Simard. L., \& Spencer, K.). (2004). Sharing our success: Ten case studies in Aboriginal schooling. Kelowna, BC: Society for the Advancement of Excellence in Education. Retrieved from http://dspace.hil.unb.ca:8080/bitstream/handle/1882/8733/SOS2004.pdf

Bernard, H.R. (2002) Research Methods in Anthropology: Qualitative \& Quantitative Approaches. Walnut Creek, CA: Alta Mira.

Bérubé, J. (1994). Récit et analyse d'une experience d'enseignement en milieu autochtone. Montréal, QC: Université de Montréal.

Blacksmith, G. (2000). Educational development in the Cree schools of James Bay, Northern Québec: Twenty years of experience. Montreal, PQ: McGill University.

Blagg, H. (2011). Journeys outside the comfort zone: Doing research in the Aboriginal domain. In L. Bartels \& K. Richards (Eds.), Qualitative criminology: Stories from the field (pp. 140-154). Sydney, AU: Federation Press.

Bonspiel, S. (2002, September 2). Washaw Sibi Cree walk to new home-Hope to correct historic injustice. The Nation. Montreal, QC: Beesum Communications.

Bonspiel, S. (2006, February 17). La Tuque residential school razed. The Nation. Montreal, QC: Beesum Communications 
Bonspiel, S. (2006, September 22). A Cree pathway to southern schools. The Nation. Montreal, QC: Beesum Communications..

Bonspiel, S. (2006, October 20). The classroom in crisis. Mistissini’s school system deals with racism, high drop-out rates and cultural survival. The Nation. Montreal, QC: Beesum Communications.

Bostic, K. (2005). Bilingual education: The Cree Way Project. Ann Arbor, MI: University of Michigan. Retrieved from http://sitemaker.umich.edu/356.bostick/the_cree_way_project

Burnaby, B., Mackenzie, M., \& Salt, L.B., (1999). Native language for every subject: The Cree language of instruction project. Flagstaff, AZ: Northern Arizona University Retrieved from http://jan.ucc.nau.edu/ jar/Burnaby.html

Burnaby, B., Faries, E., Fietz, O., \& McAlpine, L. (1994). Cree Language of Instruction Grade One Program: Report of External Evaluators. Chisasibi, QC: Council of Commissioners of the Cree School Board.

Cadieux, P. H., (2005). Les relations entre le Québec et les peuples Autochtones: Vers un nouveau partenariat pour le $21^{\text {ème }}$ siècle. Québec, QC: Publications du Gouvernement du Québec.

Cameron, K. (1987). Northern educational development: The Yukon context. Paper presented at the Circumpolar Conference on Education, Iqaluit, NU.

Canadian Council on Learning. (2008). Lessons in learning. Students on the move: Ways to address the impact of mobility among Aboriginal students. Ottawa, ON: Author. Retrieved from http://www.ccl-cca.ca/pdfs/LessonsInLearning/May-1508-Students-on-the-m.pdf

Castellano, M. (2004). Ethics of Aboriginal Research. Journal of Aboriginal Health, January, 98-114.

Chakrabarty, D. (1992). Postcoloniality and the artifice of history: Who speaks for "Indian" pasts? In P. Mongia (Ed.), Contemporary post-colonial theory (pp 223227). London, England: Arnold.

Chilisa, B. (2012). Indigenous research methodologies. London, England: Sage Pulblications.

Chrisjohn, R. D., \& Young, S. L. (1997). The circle game: Shadows and substance in the Indian residential school experience in Canada. Penticton, BC: Theytus Books Ltd.

Coates, J. (2003). Ecology and social work: Toward a new paradigm. Halifax, NS: Fernwood.

Cole, T., Visser, J., \& Daniels, H. (2001). Proficient schooling for pupils with EBD. Colloqium Proceedings. The University of Joensuu, Finland. 
Conrad P. (2007). The medicalization of society. Baltimore, MD: The Johns Hopkins University Press.

Cooper, P., Smith, C.J., \& Upton, G. (1994). Emotional \& behavioural difficulties. Theory to practice. London, England: Routledge.

Córdoba, T. (2006). Aboriginal literacy and education: A wholistic perspective that embraces intergenerational knowledge. Toronto, ON: Ontario Institute of Studies in Education, University of Toronto.

Cree School Board (2006a). Annual Report 2006. Mistissini, Québec: Cree School Board.

Cree School Board (2006b). About CSB. Philosophy. Retrieved from http://www.cscree.qc.ca/index.php/philosophy (January $13^{\text {th }}, 2014$ )

Darnell, R. (1984). Interaction et language chez les Cris. Recherches Amérindiennes au Québec, 14(4), 42-50.

Davies, C. (1989). Goffman's concept of the total institution: Criticisms and revisions. Human Studies, 12 (1/2), 77-95.

Denny, J. P. (1981). Curriculum development for teaching mathematics in Inuktitut: The learning from language approach. Canadian Journal of Anthropology, 1(2), 199203.

Denzin, N. K., Lincoln, Y. S., \& Smith, L. T. (2008). Handbook of critical and Indigenous methodologies. Thousand Oaks, CA: Sage.

Edwards, K., Lund, C., Mitchell, S., \& Anderson, A. (2008). Trust the process: Community-based researcher partnerships. Pimatisiwin: A Journal of Aboriginal and Indigenous Community Health, 6(2), 186-199.

Elliott, J. (2004). Multimethod approaches in educational research. International Journal of Disability, Development and Education, 51(2), 135-149.

European Monitoring Centre on Racism and Xenophobia. (2006). Roma and travellers in public education - An overview of the situation in EU member astates. Vienna, AT: EUMC.

Fantilli, R., \& McDougall, D. (2007). Making the transition - The case for mentoring systems. Proceedings of the Hawaï $5^{\text {th }}$ International Conference on Education, Honolulu, HI.

Felt, H.A. (1995). Hunting and the quest for power: The James Bay Cree and Whitemen in the 20th century. In R. B. Morisson \& C. R. Wilson (Eds.), Native people: The Canadian experience ( $2^{\text {nd }} \mathrm{ed}$.).

Feurer, H. (1990, May). Multilingual education: An experimental project by the Cree Indians of Waskaganish in Québec, Canada. Unpublished paper presented at the International Conference on Thai Studies, $4^{\text {th }}$, Kumming, Yunnan, China. ERIC Document Reproduction Service No. ED 337045 
Fillmore, L.W. (1991). When learning a second language means losing the first. Early Childhood Research Quarterly, 6, 323-346.

Flanagan, T. (2002). Chapitre 6: Les problèmes inhérents à l'autonomie gouvernementale Autochtone. In T. Flanagan (Ed.), Premières Nations, second regards, (pp. 95119). Québec: Septentrion.

Fletcher, T.B., \& Hinkle, J S. (2002). Adventure based counselling: An innovation in counselling. Journal of Counselling and Development, 80(3), 277.

Francis, D., \& Morantz, T. (1983). Partners in furs: A history of the fur trade in Eastern James Bay 1600-1870. Kingston, ON \& Montreal, QC: McGill-Queen’s University Press.

Frenette, J. (1988). The history of the Chibougamau Crees - An Amerindian band reveals its identity. Chibougamau, QC: Cree Indian Centre of Chibougamau.

Friesen, D., \& Orr, J. (1996). Northern Aboriginal teachers’ voices: A constellation of stories. Regina, SK: Saskatchewan School Trustee Association. SSTA Research Centre Report \#96-15.

Gagné, J., M. (2006). Entente avec les communautés Autochtones: considérations pratiques. Québec, QC: Fasken Martineau.

Gagnon, A-G., \& Rocher, G. (2002). Regard sur la convention de la Baie-James et du Nord Québécois. Montréal, QC: Québec-Amériques.

Gale, K., McClay, D., Christie, M., \& Harris, S. (1982). Milingimbi bilingual education: Results in the 3Rs. In R. Lipscombe \& D. Burnes (Eds.), Aboriginal literacy: Bridging the gap (pp. 1-14). Rozette, AU.: Australian Reading Association.

Gnarowski, M. (2002). I dream of yesterday and tomorrow-A celebration of the Bay James Crees. Ottawa, ON: Golden Dog Press.

Goodman, R., \& Burton, D. M. (2010). The inclusion of students with BESD in mainstream schools: Teachers' experiences of and recommendations for creating a successful inclusive environment. Emotional \& Behavioural Difficulties, 15(3), 223-237.

Goulet, G. (2001). Two teachers of Aboriginal students: Effective practice in sociohistorical realities. Canadian Journal of Native Education, 25, 68-82.

Gouvernement du Québec. (2006). Entente Québec-Cris: La paix des braves. Publications du Gouvernement du Québec.

Grand Council of Crees. (2006). Deputy Grand Chief Ashly Iserhoff remarks at the grand opening of the Sabtuaan Regional Vocational Training Centre in Waswanipi, Québec. Nemaska, QC: Grand Council of Crees. Retrieved from http://www.gcc.ca/newsarticle.php?id=70

Hall, L. (2012). The ‘come and go' syndrome of teachers in remote Indigenous schools: Listening to the perspective of Indigenous teachers about what helps teachers to 
stay and what makes them go. The Australian Journal of Indigenous Education, 41(2), 187-19.

Hall, L., \& Fovet, F. (2012). The lonesome road: A comparative study of low retention of teachers working in Aboriginal and SEBD contexts. Global Education Review, 1(1), 9-27.

Haney, C., Banks, C., \& Zimbardo, P. (1973). A study of prisoners and guards in a simulated prison. Naval Research Reviews, 30(9), 4-17.

Hill, R. (2007). What is the role of English transition in Maori-medium education? Paper presented at Language, Education and Diversity 2007, Waikato University, NZ.

Indian and Northern Affairs Canada. (1993). La convention de la Baie-James et du Nord Québécois et la Convention du Nord-Est Québécois. Ottawa, ON: Government of Canada.

Indian and Northern Affairs Canada. (2004). Backgrounder-The residential school system. Ottawa, ON: Government of Canada.

Indian Residential Schools Resolution. (2006). Residential school history. Ottawa, ON: Government of Canada.

Kovach, M. (2010). Conversational method in Indigenous research. First Peoples Child and Family Review, 5(1), 40-48.

Kumar, M. (2000). Postcolonial theory and cross-culturalism: Collaborative "signposts" of discursive practices. Journal of Enquiry, 1(2), 82-92.

Laycock, A., Walker, D., Harrison, N., \& Brands, J. (2011). Researching Indigenous health: A practical guide for researchers. Melbourne, AU: Lowitja Institute.

Manitoba Education, Citizenship and Youth. (2005). A profile of student learning and performance in Manitoba -2003-2004. Winnipeg, MB: Author.

Matthiasson, J. S. (1979). But teacher, why can’t I be a hunter: Inuit adolescence as a double-bind situation. In K. Ishwaran (Ed.), Childhood and adolescence in Canada. Colombus, OH: McGraw-Hill.

McLeod, N. (2007). Cree narrative memory: From treaties to contemporary times. Saskatoon, SK: Purich Publishing.

MacNab, N., Visser, J., \& Daniels, H. (2007). Desperately seeking data: Methodological complications in researching 'hard to find' young people. Journal of Research in Special Educational Needs, 7(3), 142-148.

McNinch, J. (1994). The recruitment and retention of Aboriginal teachers in Saskatchewan schools. Regina, SK: Saskatchewan School Trustees Association, Research Centre Report: \#94-10.

Mendelson, M. (2008). Improving education on reserves: A First Nations Education Authority Act. Ottawa, ON: The Caledon Institute of Social Policy 
Miller, J. R. (1996). Shingwauk`s vision: A history of Native residential schools. Toronto, ON: University of Toronto Press.

Mills, J. (1972). Bilingual education in Australian schools. Australian Educational Review, 18, 96.

Modiano, N. (1975). Using Native instructional patterns for teacher training: A Chiapas experiment. Proceedings of the First International Conference on Bilingual Education, Mexico City, 1974-75.

Morantz, T. (2002). Lire la tradition orale, écrire l’histoire crie. Anthropologie et Sociétés, 26(2-3), 23-43.

Morantz, T. (2002b) 'The White man 's gotta getcha': The colonial challenge to the Crees in Quebec. Montreal, QC-Kingston, ON: McGill-Queens University Press.

Morgan, N. (2002). 'If not now, then when?' First Nations jurisdiction over education: A literature review. Vancouver, BC: First Nations Steering Committee.

Nabigon, H., Hagey, R., Webster, S., \& MacKay, R. (1998). The learning circle as a research method: The trickster and windigo in research. Native Social Work Journal, 2(1), 113-137.

Nichols, W. (2005, April 15). Residential school conference. The Nation Montreal, QC: Beesum Communications.

Nicholls, R. (2009). Research and Indigenous participation: Critical reflexive methods. International Journal of Social Research Methodology, 12(2), 117-126.

Niezen, R. (1998). Defending the land: Sovereignty and forest life in James Bay Cree society. Neidham Heights, MA: Allyn \& Bacon.

Nagel, N. (2001). Empowering young students to become active citizens through real world problem solving. Democracy and Education, 14(2), 6-9.

National Center for Education Statistics. (2008). Status and trends in the education of American Indians and Alaska Natives (NCES 2008-084). Washington, DC: Institute of Education Studies.

Ohmagari, K., \& Berkes, F. (1997). Transmission of Indigenous knowledge and bush skills among the Western James Bay Cree women of Subartic Canada. Human Ecology, 25(2) 197-222. Netherlands: Springer.

Padfield, P., \& Jordan, E. (2004). Issues in school enrolment, attendance, attainment and support for learning for Gypsy/travellers and school-aged children and young people based in Scottish local authority. Edinburgh, Scotland: STEP.

Preston, R. J. (1979). The development of self-control in the Eastern Cree life cycle. In K. Ishwaran (Ed.), Childhood and adolescence in Canada. Colombus, OH: McGrawHill. 
Raham, H. (2004). Literacy instruction in Aboriginal settings. Kelowna, BC: Society for the Advancement of Excellence in Education.

Roué, M. (2006). Healing the wounds of school by returning to the land: Cree Elders come to the rescue of a lost generation. International Social Science, 58(187), 1524.

Royal Commission on Aboriginal Peoples.(1996). Volume 5, renewal: A twenty-year commitment (Appendix E). Report of the Royal Commission on Aboriginal Peoples. Ottawa, ON: Canada Communications Group. Retrieved from http://qspace.library.queensu.ca/bitstream/1974/6874/1/RRCAP5_combined.pdf

Russo, C.D. (1983) Developing educational policies for traditionally oriented Aborigines. Interchange, 14(2), 1-13.

Santoro, N., Reid, J., Crawford, L., \& Simpson, L. (2011). Teaching Indigenous children: Listening to and learning from Indigenous teachers. Australian Journal of Teacher Education, 36(10), 65-76.

Savides, D.M. (2000). Cooperative learning in a Cree community: A small experiment, 1996-1998. Montreal, PQ: McGill University.

Sawatsky, J. (2009). The ethic of traditional communities: The spirit of healing justice. Toronto, ON: Jessica Kingsley Pub.

Schnarch, B. (2004). Ownership, control, access, possession (OCAP) or selfdetermination applied to research: A critical analysis of contemporary First Nations research and some options for First Nations communities. Ottawa, ON: National Aboriginal Health Organization.

Scott, C. (1986). Hunting territories, hunting bosses and communal production among coastal James Bay Cree. Anthropologica, 28(1/2), 163-173.

Scott, C. (1988). Property, practice and Aboriginal rights among Québec Cree hunters. In T. Ingold, D. Riches, \& J. Woodburn (Eds.), Hunters and gatherers 2: Property, power and ideology. Oxford, England: Berg Publishers Limited.

Scott, C. (2002). Aboriginal autonomy and development in Northern Quebec and Labrador. Vancouver, BC: University of British Colombia Press.

Simpson, L., \& Driben, P. (2000). From expert to acolyte: Learning to understand the environment from an Anishinaable point of view. American Indian Culture and Research Journal, 24(3), 1-19.

Smith, L. T. (1999). Decolonizing methodologies: Research and Indigenous peoples. New York, NY: St. Marten's Press.

Smith, M. (2001). Relevant Curricula and School Knowledge: New Horizons. In: Aboriginal Education in Canada: A Study of Decolonization . (pp.77-88). Mississauga. Educators Press 
Spivak, G. (1990). Post-structuralism, marginality, post-coloniality and value. In P. Mongia (Ed.), Contemporary post-colonial theory (pp 198-221). London, England: Arnold.

Standing Senate Committee on Aboriginal Peoples. (2011), Reforming First Nations wducation: From xrisis to hope. Ottawa, ON: Author.

Staniforth, J. (2013, May 17). Looking back in order to move forward. The Nation. Montreal, QC: Beesum Communications.

St. Denis, V. (2002). Exploring the socio-cultural production of Aboriginal identities: Implications for education. Unpublished doctoral dissertation, Stanford University School of Education, Stanford University, Stanford, California. Retrieve from http://search.proquest.com/docview/305527599

St. Denis, V., \& Hampton, E. (2002). A review of literature on racism and the effects on Aboriginal education. Paper prepared for Minister's National Working Group on Education. Ottawa, ON: Indian and Northern Affairs Canada. Retrieved from http://iportal.usask.ca/index.php?t=display_solr_search\&having=999329\&sid=51 $\underline{8553411}$

Steinhauer, E. (2002). Thoughts on an Indigenous research methodology. Canadian Journal of Native Education, 26(2), 69-81.

Sternberg, R. (1997). What does it mean to be smart? Educational Leadership, 54(6), 6674.

Stewart, C. (2005). Indigenous teachers: Narratives of identity and change. Unpublished Masters Thesis. Simon Fraser University, Vancouver, B.C. Retrieved from Tajfel, H. (1970). Experiments in intergroup discrimination. Scientific American, 223(5), 96-105.

Tanner, A. (1979). Bringing home animals: Religious ideology and mode of production of the Mistassini Cree Hunters. Memorial University of Newfoundland, Institute of social and Economic Research, Social and Economic Studies, No 23.

Tashakkori, A., \& Teddlie, C. (2003). Handbook of mixed methods in social and behavioural research. Thousand Oaks, CA: Sage Publications, Inc.

Thistle, P. (1986). Indian-European trader relations in Lower Saskatchewan River Region to 1840. Winnipeg, MB: University of Manitoba Press.

Tsuiji, L.J.S. (1996). Loss of Cree traditional ecological knowledge in the Western James Bay region of Northern Ontario, Canada: A case study of the sharp-tailed grouse. The Canadian Journal of Native Studies, 16(2), 283-292.

Tulloch, S., Holt, A., Pilakapsi, Q., \& Lyall, E. (2007). The pursuit of bilingual, biliterate communities in Nunavut. Paper presented at Language, Education and Diversity 2007, Waikato University, NZ. 
Ungar, M. (2002). Playing at being bad-The hidden resilience of troubled teens. East Lawrencetown, NS: Pottersfield Press.

Villegas, M., Neugebauer, S. R., \& Venegas, K. R. (2008). Indigneous knowledge and education: Sites of struggle, strength, and survivance. Cambridge, MA: Harvard Educational Review.

Visitor, L. (1999). La cérémonie de la marche. Chisasibi, QC: The Cree School Board.

Visser, J. (2000). School environment and absenteeism. Paper presented at "To Play Truant” Conference, Hamburg, Germany, University of Hamburg.

Wanat, C. (2008). Getting past the gatekeepers: Differences between access and cooperation in public school research. Field Methods, 20(2), 191-208.

Weber-Pillwax, C. (2001). What is Indigenous research? Canadian Journal of Native Education, 25(2), 166-174.

Whitehead, T.L. (2004). What is ethnography? Methodological, ontological and epistemological attributes. Ethnographically Informed Community and Cultural Assessment Research Systems (EICCARS) Working Paper Series. University of Maryland: Author. Retrieved from http://www.cusag.umd.edu/documents/WorkingPapers/EpiOntAttrib.pdf

White, J. P., \& Peters, J. (2009). A short history of Aboriginal education in Canada. In J. P. White, J. Peters, D. Beavon, \& N. Spence (Eds.), Aboriginal education: Current crisis and future alternatives (pp. 13-31). Toronto, ON: Thompson Educational Publishing.

Williams, E., Guenther, J., \& Arnott, A. (2011, November 23). Beyond informed consent: How is it possible to ethically evaluate Indigenous programs? Paper presented to the NARU Public Seminar Series, Charles Darwin University.

Wotherspoon, T. (2008). Teachers' work intensification and educational contradictions in Aboriginal communities. The Canadian Review of Sociology, 45(4), 389-418.

Wright, R. M. (1988). Anthropological presuppositions of Indigenous advocacy. Annual Review of Anthropology, 17, 365-90.

Wright, S.C., \& Taylor, D. M. (1995). Identity and the language of the classroom: Investigating the impact of heritage vs. second language instruction on personal and collective self-esteem. Journal of Educational Psychology, 87(2), 241-52.

Wyatt, J. (2009). Behavior analysis in the era of medicalization: The state of the science and recommendations for practitioners. Behaviour Analysis in Practice, 2(2), 4957.

Yorkshire Museums, Libraries \& Archives Council. (2005). Working with travellers and Gypsies. A resource bank. Leeds, England: Yorkshire Museums, Libraries \& Archive Council. 